Plukovník Mgr. Ladislav Chaloupský, Ph.D.

Problematika překladu vojenských

hodností

Válčíme s jazykem. Mezi námi a jazykem je válka.

L. Wittgenstein

\title{
Úvod
}

Citát rakouského logika a filozofa L. Wittgensteina, autora Tractatus Logico-Philosophicus, plně vystihuje obtížnost toho, s čím se překladatel musí každodenně potýkat.

Vzájemná výměna informací je možná jen mezi lidmi, kteří mluví společným jazykem. A protože se odhaduje, že ve světě existuje okolo 7000 [1] samostatných jazyků, je zřejmé, že taková komunikace a vzájemná výměna informací je problematická. Možnost, jak vyřešit tento problém týkající se mezinárodní komunikace, by mohl spočívat v používání jednoho jazyka. Bohužel žádný takový společný jazyk zatím neexistuje.

Ze živých jazyků se ve středověku takovému společnému jazyku na diplomatické úrovni blížila latina. Od vestfálského míru v roce 1648, jímž skončila třicetiletá válka, platila za tzv. mezinárodní diplomatický jazyk francouzština a od konce první světové války se prosazuje jako jazyk „mezinárodní“ komunikace angličtina.

Další možností, jak usnadnit mezinárodní komunikaci, by mohl být pomocný, umělý jazyk. [2] V průběhu doby byla vytvořena řada umělých jazyků. Mezi nejznámější patří Volapük, Esperanto, Ido, Okcidental, Novial a další. Jejich výhodou je sice relativní jednoduchost gramatických pravidel, ale vědecká či obchodní sdělení, nebo sdělení na diplomatické úrovni se jimi dají vyjadřovat obtížně.

Ale ani o jednom z těchto jazyků ,živých a umělých“ se nedalo a nedá tvrdit, že by plně umožňoval nebo umožňuje komunikaci mezi národy celého světa. A protože, jak vidíme, doposud neexistuje žádný mezinárodní jazyk, osoba, která mluví jenom jedním jazykem, potřebuje k dorozumění s osobou, která mluví jiným jazykem, zprostředkovatele, který oba jazyky ovládá. Tlumočník nebo překladatel tedy vstupuje do procesu komunikace mezi subjekty mluvícími rozdílnými jazyky jako nutný mezičlánek.

\section{Historie překladu}

The story of language is the story of human civilization.

Nowhere is civilization so perfectly mirrored as in speech. Mario Pei, The Story of Language, 1949

Prvopočátky překladu jsou spojeny se vznikem písma. V muzeích jsou toho dokladem slovníky na hliněných tabulkách, které jsou psané klínopisem. Nejznámější příklad, který ilustruje tisíciletou historii překladu, je rosettská deska, nalezená vojáky Napoleonovy armády při jeho válečném tažení do Egypta. Francouzští vojáci si uvědomili neobvyklost objevu a předali tuto desku archeologům, kteří vojsko doprovázeli. Na desce jsou 
vyryty tři stejné texty. Dva z těchto textů byly do té doby neznámé. Jednalo se o písmo hieroglyfické [3] určené pro nejvyšší vrstvy společnosti a písmo démotické pro úředníky. A právě třetí, identický text v řečtině pro Řeky žijící v Egyptě umožnil rozluštit výše uvedené dva texty.

Ve třetím tisíciletí před naším letopočtem asyrský král Sargon II. Akkadský nechával zapisovat své vojenské úspěchy v různých jazycích. Faraon Psammték I. posílal egyptské děti ve věku od 7 do 14 let do Řecka, aby se naučily řecky a seznámily se s řeckou kulturou. Tyto osoby po návratu působily jako úředníci-překladatelé. Babylonský král Chammurapi vydává v několika jazycích na počátku druhého tisíciletí svoje edikty. Byzantský císař Konstantin VII. založil v rámci diplomatických služeb školu pro tlumočníky a překladatele, kteří mimo jiné vykonávali i špionážní činnost. Na dvoře císaře Rudolfa II. se už používal titul dvorní tlumočník a Marie Terezie hierarchicky povyšuje tento titul na název tlumočnický adjunkt.

\section{Překlady sakrálních textů}

Verba volant, skripta manent. [4]

Latinské přísloví

Překlady sakrálních textů mají v historii překladu specifické postavení. Ve druhém století našeho letopočtu byly ze sanskrtu do čínštiny přeloženy buddhistické svaté texty. Ve dvanáctém a třináctém století kvetlo překladatelství v Toledu, kde dvojice, případně týmy př̀kladatelů překládaly nejenom sakrální texty hebrejské, arabské, latinské a řecké, ale také texty profánní.

Nejvyššího uznání se však dostalo překladu, když byla do latiny přeložena Bible. Tento latinský text se stal základním ideologickým dokumentem středověku. Církev sice trvala na tom, aby se sakrální texty překládaly doslova, aby se zachoval počet překládaných slov a pořadí slov ve větě, aby se doslova překládaly idiomatické a frazeologické vazby, ale mnohé z takto přeložených textů byly téměř nesrozumitelné. Proto svatý Jeroným [5] použil pro překlad Bible do latiny, tzv. Vulgáty, volnější, srozumitelnější překlad. A jak už se to v historii často stává, byl obviňován za porušení církevních dogmat, za tzv. překroucení učení Kristova.

V této souvislosti se musíme zmínit o překladu Písma z řečtiny do staroslověnštiny Cyrilem a Metodějem počátkem roku 862. Ve zlomku je zachován také traktát o překladatelských postupech evangeliáře, známý jako „Hilferdingův makedonsko-cyrilský list“. Je často považovaný za první slovanskou teorii překladu.

Dochované české překlady pocházejí z 11. a 12. století, jedná se nejdříve o tzv. staročeské glosy a později o evangelia a žalmy. Nejstarší dochovaný žaltář, který pochází ze dvou překladových verzí, je žaltář Wittemberský.

O těchto biblických překladech se zmiňuji ze dvou důvodů. Ten první důvod je, že překlady Bible do staroslověnštiny a češtiny byly důležité pro vývoj českého spisovného jazyka, protože představovaly normu ,vznešené použití jazyka“ pro posvátný text. Díky těmto překladům se vytvořil a ustálil psaný český jazyk a ze sporu o český jazyk používaný v biblických překladech vznikly i první české gramatiky.

Druhý důvod je ten, že s historií překladu Bible souvisí jeden z nejdéle trvajících př́kladů chybného překladu, který má dodnes hmatatelné dopady. Jednu z významných 


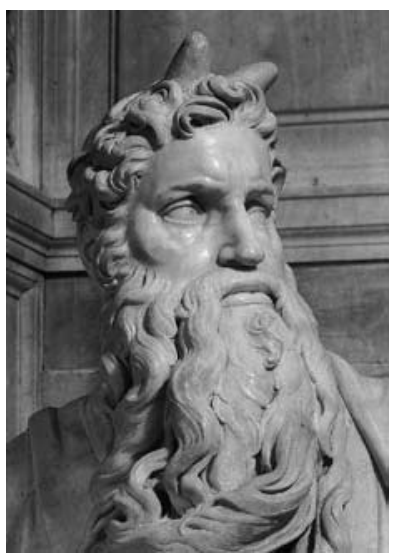

Obr.: Michelangelo Buonarotti, Mojžřš, mramor, chrám sv. Petra v Římě, cca 1513-1515.

starozákonních postav, Mojžíše, vypodobnil na počátku šestnáctého století Michelangelo Buonarotti jako postavu, která má na hlavě rohy. Dnes můžeme téměř s jistotou konstatovat, že za označení Mojžíše s rohy může nepřesný překlad hebrejských textů. Místo správného slova velebený či osvícený/osvětlený bylo přeloženo podobné hebrejské slovo „rohatý“.

\section{Odborný styl, překlad a slovníky}

What's in a name? That which we call a rose

By any other name would smell as sweet.

William Shakespeare, Romeo and Juliet, II.2.43-44

Pokusy o definování překladatelských problémů, odborných i všeobecných, jsou spojovány s antikou. Již staří Římané se zabývali rozdíly mezi překladem volným a doslovným. Uznávali užitečnost překladu v rámci výuky cizích jazyků, ale také jeho užitečnost při zdokonalování se ve vlastním jazyce. Maimonides, středověký fillozof a lékař, uváděl, že pro překlad slova je rozhodující kontext. Jan Hus se v úvahách o překládání biblických reálií zabýval vztahem mezi pojmem a jeho slovním vyjádřením.

Postupně vzniká věda o překladu, která se časem vzhledem k dané problematice a rozsahu vyčleňuje v rámci lingvistiky jako samostatný vědní obor. [6] Součástí vědy o překladu je teorie odborného překladu. Nicméně přesně definovat termín odborný překlad, nebo termín překlad odborných textů je obtížné. Často se pod těmito pojmy rozumí překlad technický a vědecký. Jeho předmětem jsou podmínky a jevy, které souvisejí s převodem odborného stylu, a to jak na úrovni lexikální, tak v rovině syntaktické. Odborný styl je specifický druh, který se týká věd exaktních, přírodních a věd společenských. Je zřejmé, že jinak budeme popisovat např́klad letoun nebo tank a jinak krásu české krajiny. Odborný styl se vyjadřuje větším počtem nocionálních slov, neosobností projevu, prvky expresivní se omezují na minimum a využívají se ve větší míře pasivní formy.

Základním předpokladem pro správně provedený odborný překlad je přesnost. Ta přímo souvisí s překladatelovou vzdělaností. Pokud se má překlad co nejvíce blížit originálu, musí překladatel nejenom dokonale znát jazyk, do kterého překládá, ale musí také rozumět kultuře a reáliím společenství, které tento jazyk používá. Jinými slovy, překladatel musí provést stylistickou a sémantickou analýzu textu.

Pokud vyjdeme z premisy, že armáda jako celek zahrnuje specializované útvary, které při své činnosti používají odborné termíny, dojdeme k závěru, že překlad týkající se vojenské tematiky spadá do oblasti odborného překladu a analogicky také zařadíme překlad vojenských hodností do kategorie odborného překladu.

Při tomto typu překladu je ve většině případů nutnost použít odborných (vojenských terminologických) slovníků, které poukazují na nejenom polysémantičnost výrazů, 
a navíc se musí pečlivě zvážit, zda daný výraz odpovídá př́ílušnému kontextu. $\mathrm{Ne}$ každý slovník těmto požadavkům vyhovuje, a proto se výběru slovníků musí věnovat náležitá pozornost. Některé jsou určeny převážně pro studenty anglického jazyka a uváděné termíny jsou proto vysvětlovány zjednodušeně, jiné slovníky mohou uvádět dokonce zavádějící či nepřesné termíny, a jiné slovníky, které si pořizujeme, mohou být identické, aniž si to při koupi uvědomíme.

Například britský slovník Dictionary of Military Terms z nakladatelství Peter Collin Publishing existuje i v dalších verzích. Je vydáván britským nakladatelstvím Macmillan s názvem Campaign, Dictionary of Military Terms, britským nakladatelstvím A \& C Black Publishers Ltd., a také americkým nakladatelstvím Fitzroy Deaborn Publishers pod názvem Dictionary of Military Terms. Každý z těchto slovníků má sice jinou titulní stranu, ale stejného autora/redaktora, a obsahuje téměř identická slovníková hesla. Přes nespornou užitečnost tohoto či těchto slovníků si musíme dávat pozor na uváděné definice.

Výše uvedené slovníky například definují, že heslo warrant officer v americké variantě angličtiny je non-commissioned officer, což neodpovídá skutečnosti. Pokud v těchto slovnících vyhledáme definici hesla non-commissioned officer, zjistíme, že tento termín je definován přesněji.

\section{Vojenský jazyk a překlad}

Znalost jazyků je hlavní branou k moudrosti. Roger Bacon

Po celou dobu vojenské historie si vládci uvědomovali neocenitelné služby překladatelů a tlumočníků pro vydávání rozkazů a dobývání cizích území, a to nejenom při svých válečných taženích, ale také při vyjednávání a spravování získaných území.

V dnešní době se důležitost a význam práce lingvistů, překladatelů a tlumočníků neustále zvyšuje. Jejich znalosti a zkušenosti se využívají v kryptografii a steganografii. Analýzou textů a promluv se zabývá např́klad forenzní lingvistika. [7] Zpravodajské služby analyzují různé druhy projevů a zjištujú jejich identitu a sociální kontext. V rámci NATO se zvyšují požadavky na přesnost a pohotovost tlumočení a prováděných překladů. Většina takových překladů souvisí s tzv. vojenským jazykem.

Vojenský jazyk je soubor jazykových prostředků národního jazyka používaných ve vojenském dorozumívacím stylu. Vojenské termíny, které se v tomto souboru jazykových prostředků (odborné i neodborné) používají, procházejí vývojem, který koresponduje s historickými fázemi vojenství. Zvládnout tyto termíny v cizím jazyce na určité úrovni musí každý, kdo chce úspěšně komunikovat se zahraničními delegacemi doma i v zahraničí, př́ípadně komunikovat při plnění bojových úkolů. Jedná se však o nesmírně náročný a dlouhodobý proces. Ale i když je tento proces studia zvládnut úspěšně, neznamená to mít schopnost dobře překládat, nebo tlumočit.

Tlumočení a překladatelství jsou dvě samostatné vědní disciplíny, které nelze slučovat do jednoho oboru, a které vyžadují celoživotní vzdělávání. Při jakémkoliv, nejenom vojenském, překladu musíme nejdříve text analyzovat, definovat význam, a poté tento význam převést adekvátně do cílového jazyka (viz obr. 1). 
Výchozí jazyk

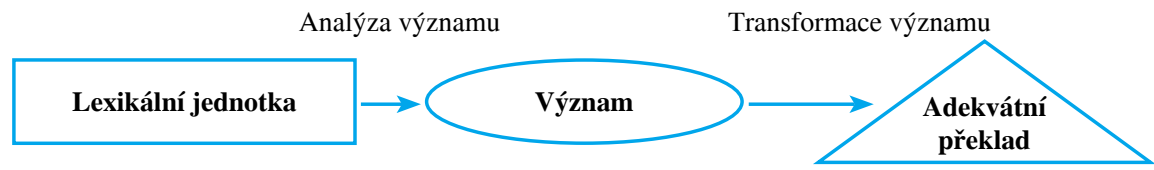

Obr. 1: Průběh překladu lexikální jednotky

\section{Překlad vojenských hodností}

Při překladu vojenských hodností do angličtiny si musíme uvědomit, že se jedná o druh odborného překladu, jak už jsme dříve uvedli, který se vyznačuje určitými specifiky. Jinými slovy, překlad vojenských hodností není překlad textu, pro který platí jiná pravidla, ale jedná se o překlad nezávislých, samostatných významových lexikálních jednotek, kde musíme správně pochopit význam jak složky denotační, tak konotační a pragmatické. Význam těchto složek nemusí vždy plně korespondovat se složkami cílového jazyka, tedy jazyka, do kterého překládáme. V takových případech hovoříme o takzvané částečné či nulové ekvivalenci překladu.

Na první pohled se může zdát výhodou, že na rozdíl od překladů textu, at' už se jedná o překlad krásné literatury, nebo překlady technické, se nemusíme zabývat překladem gramatických jevů. Dále může vzniknout dojem, že při tomto druhu překladu stačí jednoduše použít dvojjazyčný slovník a jednoduše výrazy substituovat. Opak je ale pravdou. Vojenská hodnost a funkce odpovídající této hodnosti reprezentuje konkrétní postavení $\mathrm{v}$ určité sociální skupině, $\mathrm{v}$ našem případě postavení v armádě. Názvy hodností v jednotlivých armádách vycházejí z vojenských a kulturních tradic daného státu a odpovídají funkcím, které se mohou a často se diametrálně liší od významu hodností a funkcí, které se používají v Armádě České republiky. Kromě toho se jejich význam v průběhu menších či větších historických období mění na základě dobových interpretačních norem. Například německá hodnost brigadeführer [8] z druhé světové války doslova znamená velitel brigády. Ve skutečnosti ale osoba s touto hodností velela divizi.

Nesprávný překlad vojenských hodností, nebo jejich vágní vysvětlení, může v praxi způsobit mnoho nedorozumění. To samozřejmě platí nejenom pro překlad hodností do angličtiny a jiných jazyků, ale i naopak, při překladu vojenských hodností do češtiny.

Například ve Francii [9] se u pozemních sil používá pro hodnost „,major“ název commandant. U letectva je název hodnosti stejný jako v AČR major. Situaci komplikuje název hodnosti major u pozemního vojska, který se volně do češtiny předkládá jako štábní praporčík. Obdobně může dojít k nedorozumění, pokud si neuvědomíme, že např. u námořnictva USA se pro hodnost plukovníka používá název captain, nebo u letectva Velké Británie název group captain. Takových př́ípadů objevíme při porovnávání hodností s různými státy mnohem víc.

Známe množství prŕíkladů. Třeba v první řadě seriálu M.A.S.H. je velitel jednotky M.A.S.H. oslovován jako plukovník, i když kdo zná americké vojenské hodnosti vidí, 
že jde vlastně o podplukovníka. Při běžné konverzaci se vojenské hodnosti v rámci úspornosti v angličtině - na rozdíl od češtiny - zkracují, a tak se místo oslovení lieutenant colonel používá pouze oslovení colonel. Pplk. se se jako oslovuje jako plukovník i tehdy, když velí odloučené jednotce, nebo zastává funkci na kterou je plánována hodnost plukovníka. [10]

V roce 1994 jsem tlumočil americké delegaci seržantů v platových třídách E - 6-8. Přestože jsem při tlumočení do češtiny používal vždy slovo seržant a příslušnou platovou třídu, objevila se v tisku zpráva, že se americkým desátníkům a četařům věnovali plukovníci a že se na závěr této pracovní návštěvy těmto vojákům věnoval dokonce generál AČR. Většina populace si v té době totiž přestavovala desátníka nebo četaře jako vojáka, který vykonával dvouletou základní službu a který měl minimum vojenských odborných zkušeností.

$\mathrm{V}$ př́ípadě výše uvedené delegace však byla tato asociace mylná. Jednalo se o seržanty, profesionály, kteří v armádě USA strávili 15-20 let, se zkušenostmi z bojových misí, s vysokoškolským vzděláním, a kteří zodpovídali za materiál a osoby v rozsahu takových funkčních povinností, jaké v té době zastávali naši kapitáni a majoři.

Na misi NTMI [11] v Bagdádu došlo několikrát k nedorozumění, když jeden důstojník NATO nesprávně používal termín flag officer [12] ve významu praporčík. Na základě jeho oznámení velení NTMI očekávalo př́ijezd generála, ale ten nepřijel. Dotyčný důstojník neskrýval úžas, když se mu vysvětlilo, co se pod tímto názvem skrývá.

Jiný příklad chybného překladu, který se vztahoval k vojenským hodnostem, se nedávno objevoval v našem tisku. Zprávy, že v letadlech jsou prŕitomni (letečtí/ létající) maršálové, kteří se starají nejenom o bezpečnost cestujících, ale také samotná letadla hlídají, byly matoucí. V tomto případě se jedná o téměř školní ukázku nesprávného překladu. Marshal sice v některých armádách znamená vojenskou hodnost, ale v tomto př́ípadě se podle daného kontextu jedná o policejního důstojníka, strážce nebo ochranku (air-sky marshal).

Jak už bylo zmíněno dříve, vlastní název hodnosti je samostatná lexikální jednotka, která je limitována určitým počtem slov. Překládáme tedy samostatně stojící jednoslovnou, dvouslovnou, případně trojslovnou lexikální jednotku, a už tento fakt způsobuje určité potíže. Lexikální jednotky, které jsou v textu, rozvíjejí svůj informační obsah $\mathrm{v}$ rámci celého textu. $\mathrm{V}$ teoriích o přeložitelnosti textů najdeme axiom, že text je přeložitelný vždycky, i když další axiom nás upozorňuje na skutečnost, že patrně neexistuje překlad bez chyb nižšího řádu. Struktury nižšího řádu, slova, sousloví a věty, bývají přeložitelné hưř (viz tab. 1 na str. 95). Samostatných lexikálních jednotek výchozího jazyka, které jsou identické s lexikálními jednotkami cílového jazyka, existuje málo a stupeň přeložitelnosti je velmi malý. V mnoha př́ípadech se ekvivalenty bud' překrývají, nebo chybí.

Pokud se tedy hodláme zabývat překladem českých vojenských hodností do angličtiny, musíme si uvědomit význam nejenom českého názvosloví, ale také význam názvosloví anglického. Proto si, alespoň pro ilustraci, vysvětleme úskalí některých českých a anglických termínů vztahujících se k hodnostem. Příslušníci AČR se při svém působení v zahraničí nejčastěji setkávají s protějšky z armády USA a vzniká tendence přiřazovat názvy našich hodností k hodnostem armády USA. Z tohoto důvodu se názvy vojenských hodností a jim příbuzných termínů v angličtině budou primárně vztahovat k americkému názvosloví. 
Tab. 1: Přeložitelnost

\begin{tabular}{|l|c|c|c|c|}
\hline Stupeň přeloy̌itelnosti & SLOVO & SOUSLOVÍ & V̌̌TA & TEXT \\
\hline Velký (V) & & & & V \\
\hline Střední (S) & & & S & S \\
\hline Malý (M) & & M & M & M \\
\hline Velmi malý (VM) & VM & VM & VM & VM \\
\hline
\end{tabular}

\section{Hodnostní sbor mužstvo}

Začněme českým výrazem mužstvo. Tento výraz je sice dnes kodifikován slovníky spisovného jazyka českého jako souhrnný název pro vojíny, ale opětovným zavedením hodnosti svobodník do kategorie mužstva dochází ke rekodifikačnímu stavu z první republiky. Český výraz mužstvo, ale také jeho anglický ekvivalent men, konotuje pouze muže. Dříve se ženy v armádách objevovaly pouze sporadicky. Dnes jich však v moderních armádách slouží významné procento, a proto se v angličtině používání termínu men omezuje nejenom ve významu mužstvo, ale omezuje se také jeho uvádění v dalších termínech a složeninách. [13] Existuje sice anglický kolektivní výraz pro ženy distaff, stejně jako v češtině existuje pro ženy kolektivní výraz ženstvo, ale $\mathrm{v}$ tomto př́padě se jedná o úzce frekventovaný termín. Spojení men and distaff tedy není stylisticky správné z důvodu spojení všeobecného termínu s málo frekventovaným termínem. Vzbuzovalo by to úsměv na rtech, asi jako kdybychom obdobně v armádě používali sousloví mužstvo a ženstvo. Jako vhodnější by se ukazovalo použít sousloví staff and distaff, ale ani tento překlad nesplňuje z výše uvedených důvodů požadavky na adekvátní překlad.

Občas se pro překlad termínu mužstvo do angličtiny používaly výrazy rank and file a enlisted. [14] První výraz se dříve používal v angličtině pro osoby, které nezastávaly žádné velitelské funkce, tedy pro hodnosti dle dnešních platových trríd E-1-4. V současné době se termín rank and file používá spíše ve stylu hovorovém, a to s určitou humornou nadsázkou. Druhý, oficiální termín v armádě USA, enlisted, zahrnuje hodnosti, které jsou zařazeny v platových třídách E - 1-9, (viz tab. 3 a 4). Tento výraz implikuje určitý časový závazek. Každý enlisted podepsal určitou dobu závazku a po jeho ukončení je bud' propuštěn, anebo si závazek může prodloužit. Jeho případné prodloužení záleží na požadavcích armády a na tom, jak si dotyčný voják nebo vojákyně plní své povinnosti. Vzhledem k rozsahu významu a použití tohoto termínu jej nelze do češtiny přeložit jinak než opisem. Jedná se o př́klad bezekvivalentnosti.

Hodnostní sbor mužstvo lze do angličtiny překládat jako sousloví privates and lance corporals, př́ípadně jako recruits. Avšak ani jeden z těchto návrhů není ideální, protože plně nevystihuje jejich realitu. Překlad tohoto hodnostního sboru jako enlisted je za daného stavu naprosto neadekvátní.

V britské armádě se jako ekvivalent amerického termínu enlisted používá u pozemního vojska termín other ranks. U britského námořnictva se však termín enlisted používá, je to dáno historicky. Počet osob a označení jejich platových tříd zařazených v kategorii other ranks je v Británii na rozdíl od armády USA jiné. 


\section{Hodnostní sbor poddůstojníci}

Stručně jsme se zmínili o termínu mužstvo, zaměřme se nyní na termín poddůstojník. Hodnosti, které se zahrnovaly do hodnostního sboru poddůstojníků, se v různých státech v průběhu historie měnily. V současné době do tohoto sboru patří v AČR tř̌i hodnosti: desátník, četař a rotný. Hodnostní sbor poddůstojníků se často do angličtiny překládá termínem non-commissioned officers (NCOs), někdy sub-officers, ale opět si musíme uvědomit významové rozdíly. Historie NCOs začíná v USA se vznikem kontinentální armády v roce 1775 a jedná se zde o směsici vojenských tradic britských, francouzských a pruských. V současnosti zahrnuje termín NCO u pozemního vojska v armádě USA devět různých hodností, viz tab. 4 (str. 98). Jedná se o hodnosti od corporal výše. Jinými slovy, tento výraz zahrnuje hodnosti, které jsou zařazeny ve třídě E - 4-9. A aby situace nebyla jednoduchá, v platové tř́íě E-4 existuje ještě hodnost [15] specialist, která však do kategorie NCO není zahrnuta. Hodnost specialist má ten, kdo na rozdíl od hodnosti corporal (která je ve stejné platové třídě) nemá zodpovědnost za podřízené osoby. Hodnost specialist může získat v armádě v USA už v základním výcviku ten, kdo před vstupem do armády absolvoval vysokou školou. V platových třídách E-8 a E-9 jsou dvě a tři hodnosti. Každá z těchto hodností má odlišné povinnosti a pravomoci. V platové třídě E-9 je sergeant major (SGM), který je obvykle zařazen na praporní úrovni, a command sergeant major (CSM), který bývá zařazen na brigádní úrovni. Sergeant major of the army [16] je u pozemního vojska pouze jeden, působí jako poradce náčelníka štábu pozemního vojska (přibližný ekvivalent našeho náčelníka generálního štábu) a dohlíží na všechny NCO u pozemního vojska. Tato hodnost se svým funkčním popisem blíží české hodnosti štábní praporčík. Tak je to ostatně uvedeno i v převodníkové tabulce NATO, ve STANAGu 2116 edice 6/2010 (viz tab. 10 na str. 102). Pokud se budeme přidržovat překladu rotný do angličtiny jako staff sergeant, pak lze kategorii poddůstojníků kolektivně překládat jako sergeants.

\section{Hodnostní sbor praporčíci}

Hodnost praporčík se obvykle do anglického jazyka překládá jako warrant officer. Tento termín má původ v námořní terminologii Velké Británie ze 13. století. V té době mladí a nezkušení příslušníci šlechty, kteří vstupovali do námořnictva, získávali důstojnické hodnosti bez předchozí praxe, a proto se museli po odborné stránce obracet na zkušené námořníky, kteří jim radili. Tito námořníci jako např́íklad lod'mistr, lodní hospodář, lodní lékař, tesař, dělostřelec a další dostávali tzv. dekret (warrant), který je odlišoval od námořníků bez profese. V anglofonních zemích jsou v současné době u některých druhů vojsk warrant officers, odborníci v určitých specializacích, kteří však nezastávají velitelské funkce. Mohou to například být i piloti vrtulníků. Dostávají jmenovací dekret a mají na rozdíl od enlisted neomezenou dobu služby. Tato kategorie hodností je nižší než poručík (dříve nižší než podporučík), ale vyšší než NCO (př́padně cadet). V armádě USA postrádá hierarchie tohoto hodnostního sboru svým způsobem logiku. Začíná hodností Warrant Officer 1 a hned poté následuje hodnost Chief Warrant Officer 2. Logicky by měla následovat hodnost Chief Warrant Officer 1, ale ta není oficiálně zavedena, nehledě na skutečnost, že chief bývá obvykle jeden. 
Pro zajímavost stojí za to uvést, že sbor Warrant Officers byl při založení letectva USA podle vzoru pozemního vojska v 1947 sice zaveden, ale později byl tento sbor zrušen.

Na rozdíl od původu anglického termínu warrant officer má český výraz praporčík poněkud jinou etymologii. Pochází z praslovanštiny a je odvozen od slova prapor, [17] obdobně jako praporečník, tedy osoba, která nese prapor. I když počet hodností je v této hodností kategorii v armádě USA pět, stejně jako v AČR, tyto hodnosti nekorespondují ve svém rozsahu funkčních povinností. Překlad těchto hodností používaných v armádě USA [18] do češtiny jako praporčík je neadekvátní, [19] přestože se tento překlad v průběhu doby vžil. Proto by se jeho použití v překladu mělo vždy důkladně zvážit, případně ponechat anglický termín s českým vysvětlením, poznámkou v textu, která by význam, tj. funkci a funkční náplň této hodnosti vysvětlila.

\section{Hodnostní sbory nižších a vyšších důstojníků}

\section{a hodnostní sbor generálů}

Důstojník je termín, který pochází z praslovanského adjektiva důstojný a označoval osobu dostatečně způsobilou k vykonávání nějaké funkce. V dnešní době si pod pojmem důstojník představíme vojáka v hodnosti poručíka až plukovníka, [20] viz tab. 6 . Tento termín sice překládáme do angličtiny jako officer a zpětně zase jako důstojník, ale jedná se o překlad pouze přibližný, protože význam slova důstojník je v češtině zúžen pouze na několik hodností ve srovnání s anglickým slovem officer. Ten v angličtině zahrnuje nejenom hodnosti důstojníků, ale navíc několik dalších hodnostních kategorií, viz tab. 7 (str. 99).

V anglické vojenské terminologii je termín officers [21] definován jako obecný termín, který zahrnuje následující vojenské kategorie: General Officers, [22] Warrant Officers a v širším slova smyslu také kategorii Non-commisioned Officers. Jinými slovy, anglický termín officers zahrnuje většinu armádních hodností. V armádě USA začíná termín $N C O$ od hodnosti desátníka, tedy vojáka v platové třídě E-4 a výše. Pokud bychom chtěli být přesní, pak by se plurál termínu officers překládal následovně: hodnosti od desátníka až po armádního generála. V př́ípadě singuláru musíme u překladu tohoto termínu věnovat pozornost tomu, ke kterému hodnostnímu sboru či kategorii se vztahuje, a teprve na základě tohoto vztahu a kontextu termín přeložit, nebo opsat. Pokud by termín odkazoval v kontextu na vojáka v kategorii Senior Field Officers, nebo Junior Field Officers, přeložili bychom ho do češtiny ekvivalentem důstojník. Pokud by se termín officer v textu vztahoval k Non-commissioned Officers, přeložili bychom ho do češtiny slovem poddůstojník. Překlad slovem důstojník by byl z hlediska českého mluvčího chybný. Totéž platí i v opačném případě, při překladu z češtiny do angličtiny.

Zastavme se ještě u názvu commissioned officer. Tento termín v armádě USA zahrnuje hodnostní sbor generálů a důstojníků, počínaje nejnižší důstojnickou hodností. Commissioned officer je voják, kterému byl presidentem USA vydán dekret (commission), ve kterém ho ustanovuje do důstojnické hodnosti. Jedná se o vojáka z povolání, tzv. kariérního vojáka, který má smlouvu s vládou a do zálohy nemůže být propuštěn jinak než z organizačních důvodů nebo odchází do důchodu po odsloužené době, ale 
Tab. 2: Porovnání hodnostních sborů v AČR s pozemním vojskem v USA

\begin{tabular}{|c|c|c|c|}
\hline \multicolumn{2}{|c|}{ Armáda České republiky } & \multicolumn{2}{|c|}{ Pozemní vojsko US } \\
\hline \multicolumn{2}{|c|}{ hodnostní sbor mužstvo } & \multirow{2}{*}{\multicolumn{2}{|c|}{$\begin{array}{l}\text { Enlisted } \\
\text { Non-commissioned Officers (E-4-9) }\end{array}$}} \\
\hline \multicolumn{2}{|c|}{ hodnostní sbor poddůstojníci } & & \\
\hline \multicolumn{4}{|c|}{ hodnostní sbor praporčíci } \\
\hline & & \multicolumn{2}{|c|}{ Warrant Officers } \\
\hline $\begin{array}{l}\text { hodnostní sbor nižší } \\
\text { důstojníci }\end{array}$ & \multirow{2}{*}{$\begin{array}{l}\text { hodnostní sbor } \\
\text { důstojníci }\end{array}$} & \multirow{3}{*}{$\begin{array}{l}\text { Commisioned } \\
\text { Officers }\end{array}$} & $\begin{array}{l}\text { Junior (Grade) Officers } \\
\text { (Company Grade } \\
\text { Officers) }\end{array}$ \\
\hline $\begin{array}{l}\text { hodnostní sbor vyšší } \\
\text { důstojníci }\end{array}$ & & & $\begin{array}{l}\text { Senior (Grade) Officers } \\
\text { (Field Grade Officers) }\end{array}$ \\
\hline \multicolumn{2}{|c|}{ hodnostní sbor generálové } & & General Officers \\
\hline
\end{tabular}

Tab. 3: Enlisted u pozemního vojska USA

\begin{tabular}{|l|l|l|}
\hline \multicolumn{2}{|c|}{ ENLISTED } \\
\hline E-1 & E-2 & \multicolumn{1}{c|}{ E-3 } \\
\hline & Private (PVT/PV2) & Private First Class (PFC) \\
\hline
\end{tabular}

Tab. 4: Hodnostní sbor Enlisted a $N C O$ u pozemního vojska v armádě USA

\begin{tabular}{|l|l|l|l|l|l|}
\hline \multicolumn{7}{|c|}{ NNLISTED } \\
\hline \multicolumn{1}{|c|}{ E-4 } & E-5 & \multicolumn{1}{|c|}{ E-6 } & E-7 & \multicolumn{1}{c|}{ E-8 } & E-9 \\
\hline $\begin{array}{l}\text { Corporal } \\
\text { (CPL) }\end{array}$ & $\begin{array}{l}\text { Sergeant } \\
\text { (SGT) }\end{array}$ & $\begin{array}{l}\text { Staff Sergeant } \\
\text { (SSGT) }\end{array}$ & $\begin{array}{l}\text { Sergeant First } \\
\text { Class (SFC) } \\
\text { (SPC) }\end{array}$ & $\begin{array}{l}\text { 1. Master } \\
\text { Sergeant } \\
\text { (MSG) }\end{array}$ & $\begin{array}{l}\text { 1. Sergeant Major } \\
\text { (SGM) }\end{array}$ \\
& & & $\begin{array}{l}\text { 2. First Sergeant } \\
\text { (1SG) }\end{array}$ & $\begin{array}{l}\text { 2. Command SGT } \\
\text { Major (CSM) } \\
\text { 3. Sergeant Major } \\
\text { of the Army }\end{array}$ \\
\hline
\end{tabular}

Tab. 5: Hodnostní sbor poddůstojníků v armádě České republiky Hodnostní sbor podduistojníků

\begin{tabular}{|l|l|l|}
\multicolumn{3}{|c|}{ Hodnostní sbor poddůstojníků } \\
\hline desátník & četař & rotný \\
\hline
\end{tabular}

může být kdykoliv dle potřeby povolán zpět do služby jak doma, tak v zahraničí. Jeho závazek je svým způsobem časově neomezený, a také není omezen věkem. [23]

Obdobně jako v USA je tomu i ve Velké Británii, Austrálii a na Novém Zélandě, kde je takový dekret vydáván královnou, tzv. Queen's commission. Na rozdíl od USA se zde můžeme setkat s termíny jako např́klad short service limited commisson (SSLC), a regular commission (RC). V prvním případě se jedná o druh kontraktu, jehož délku 
určuje věk, případně příslušnost k danému pluku a daná potřeba. Druhý termín je vlastní dekret - Queen's commission.

V češtině takový kolektivní název pro generály a důstojníky neexistuje (čs. ozbrojené síly se skládají ze šesti hodnostních sborů), a navíc jsou v AČR zavedeny smlouvy na určitou dobu. Výraz commissioned je svým způsobem jedinečný a jeho použití pro osoby, které jsou obeznámeny s danou jazykovou realitou, asociuje americkou, případně britskou armádu. Při překladu do češtiny se doporučuje tento výraz vysvětlit opisem, protože se jedná o tzv. př́ípad bezekvivalentnosti, případně lze ponechat jeho anglickou verzi. Použití slova commissioned, např́íklad pro hodnostní sbor důstojníků, je při překladu z češtiny do angličtiny chybné a zavádějící.

Tab. 6: Hodnosti, které zahrnuje termín di̊stojníci v češtině

\begin{tabular}{|l|l|l|l|l|l|}
\multicolumn{3}{|c|}{ Dižstojníci } \\
\hline poručík důstojníci & nadporučík & kapitán & major & podplukovník & plukovník \\
\hline
\end{tabular}

Tab. 7: Hodnosti, které zahrnuje termín officers v angličtině

\begin{tabular}{|l|l|l|}
\hline \multirow{2}{*}{ Commisioned Officers } & General Officers & $\begin{array}{l}\text { Brigadier General } \\
\text { Major General } \\
\text { Lieutenant General } \\
\text { General } \\
\text { General of the Army }\end{array}$ \\
\cline { 2 - 3 } & $\begin{array}{l}\text { Senior (Grade) Officers } \\
\text { (Field Grade Officers) }\end{array}$ & $\begin{array}{l}\text { Major } \\
\text { Lieutenant Colonel } \\
\text { Colonel }\end{array}$ \\
\cline { 2 - 3 } & $\begin{array}{l}\text { Junior (Grade) Officers } \\
\text { (Company Grade Officers) }\end{array}$ & $\begin{array}{l}\text { Second Lieutenant } \\
\text { Lieutenant Captain }\end{array}$ \\
\hline \multirow{2}{*}{\begin{tabular}{l} 
Warrant Officers \\
\cline { 2 - 3 }
\end{tabular}} & $\begin{array}{l}\text { Warrant Officer 1/ } \\
\text { Chief Warrant Officer 2/Chief } \\
\text { Warrant Officer 3/Chief Warrant } \\
\text { Officer 4/Chief Warrant Officer 5 }\end{array}$ \\
\hline \multirow{2}{*}{$\begin{array}{l}\text { Non-commissioned } \\
\text { Officers }\end{array}$} & Enlisted (E - 4-9) & $\begin{array}{l}\text { Corporal } \\
\text { Sergeant } \\
\text { Staff Sergeant } \\
\text { Sergeant First Class } \\
\text { Master Sergeant } \\
\text { Sergeant Major of the Army }\end{array}$ \\
\hline
\end{tabular}

V souvislosti s důstojnickými hodnostmi se můžeme také setkat mimo jiné s následujícími termíny: Field Grade a Company Grade. První termín - Field Grade je kategorie, která zahrnuje hodnost major, podplukovník a plukovník. Implikuje polní, bojovou hodnost, a protože je v poli vidět v současnosti vyšších hodností méně, jedná se o zastaralejší termín. Druhý termín - Company Grade je kategorie, která zahrnuje důstojnické hodnosti, jako jsou podporučík, poručík, nadporučík a kapitán. Jedná se bud' o velitele roty, nebo hodnosti, které jsou na funkcích u roty. 


\section{Názvy vojenských hodností a NATO}

Vojenská hodnost určuje postavení a pravomoci vojáků v armádní hierarchii. Hodnosti v armádách jednotlivých členských států NATO vycházejí z různých tradic a jejich názvy se často svým významem liší a mohou se vztahovat na rozdílné funkce. Tyto významové rozdíly v chápání jednotlivých hodností mezi jednotlivými státy by mohly způsobovat potíže při plánování společných operací, při obsazování funkcí na tabulkách, při vykazování různých statistik. Proto se v rámci standardizace hodností a efektivní spolupráce mezi jednotlivými členskými zeměmi přistoupilo k vydání dokumentu STANAG 2116-NATO Codes for Grades of Military Personnel, který zavádí tzv. hodnostní převodníkové kódy, a tím standardizuje hodnosti mezi armádami členskými států. Tímto způsobem se řeší poměrně složitá situace při porovnávání hodností mezi jednotlivými členskými státy.

V současnosti platí nejnovější edice tohoto dokumentu STANAG 2116 číslo 6 ze dne 25. února 2010. Kódové označení pro důstojníky a generály je v rozsahu OF - 1-10, [24] pro ostatní hodnosti (praporčíci, poddůstojníci) je to kódové označení OR - 1-9. [25]

Názvy vojenských hodností jsou v tomto dokumentu uvedeny v mateřském jazyce daného státu a jejich přiřazení k příslušným kódům je národní záležitostí. Tuto záležitost mají na starost zástupci jednotlivých států v NATO.

Zařazení příslušníků jednotlivých armád do struktur a misí NATO se řídí popisem funkční náplně ke kterému je přiřazen kód hodnosti. Tento kód se vztahuje k odpovídající hodnosti. Osoba, která je vyslaná do struktur NATO a jejíž hodnost neodpovídá příslušnému kódu, vykonává funkci, na kterou byla vyslána.

Pro ilustraci je v tab. 9 a 10 (str. 101 a str. 102) uvedeno ze STANAGu 2116 několik př́kladů toho, jak některé státy $\mathrm{k}$ těmto kódům přiřazují hodnosti. Jsou uvedeny pouze př́iklady, které se vztahují k pozemnímu vojsku.

U důstojníků a generálů je situace vcelku přehledná, ale u hodností, které se vztahují ke kódům OR - 1-9, je situace složitější. Pro názornou ukázku toho, jak je problematika významu jednotlivých hodností komplikovaná, se lze např́ílad podívat na ekvivalent české hodnosti četaře. Této hodnosti OR-3 odpovídá hodnost vojín u pozemního vojska kanadské armády, vojín první třídy u pozemního vojska americké armády nebo desátník u pozemního vojska francouzské armády.

Vzhledem ke specifickému postavení amerického hodnostního sboru Warrant Officers, tak jak už bylo zmíněno dříve, tato kategorie není ve STANAGu 2116 o hodnostech zařazena k žádnému z uvedených kódů (OR nebo OF), ale věnuje se ji samostatný odstavec, ve kterém jsou názvy hodností a jejich kód uvedeny viz tab. 8. Pro účely NATO se jako NCO považují kódy v rozsahu OR-5 až OR-9.

Tab. 8: Samostatné hodnostní kódy pro americký sbor warrant officers

\begin{tabular}{|l|c|}
\multicolumn{1}{|c|}{ Hodnost } & Kód \\
\hline Chief Warrant Officer 5 & W5 \\
\hline Chief Warrant Officer 4 & W4 \\
\hline Chief Warrant Officer 3 & W3 \\
\hline Chief Warrant Officer 2 & W2 \\
\hline Warrant Officer 1 & W1 \\
\hline
\end{tabular}


Tab. 9: Generálské a důstojnické hodnosti vybraných členských států a jim přiřazené hodnostní kódy

\begin{tabular}{|l|l|l|l|l|l|}
\hline GRADING & $\begin{array}{l}\text { NATO } \\
\text { CODE }\end{array}$ & \multicolumn{1}{|c|}{ CZE } & \multicolumn{1}{|c|}{ USA } & \multicolumn{1}{|c|}{ FRA } & \multicolumn{1}{|c|}{ POL } \\
\hline $\begin{array}{l}\text { National } \\
\text { Title }\end{array}$ & OF-10 & No eqivalent & $\begin{array}{l}\text { General of the } \\
\text { Army }\end{array}$ & $\begin{array}{l}\text { Maréchal de } \\
\text { France }\end{array}$ & Marszałek Polski \\
\hline $\begin{array}{l}\text { General } \\
\text { Officer }\end{array}$ & OF-9 & $\begin{array}{l}\text { armádní } \\
\text { generál }\end{array}$ & General & Général d'Armée & Generał \\
\hline $\begin{array}{l}\text { General } \\
\text { Officer }\end{array}$ & OF-8 & generálporučík & $\begin{array}{l}\text { Lieutenant } \\
\text { General }\end{array}$ & $\begin{array}{l}\text { Général de Corps } \\
\text { d'Armée }\end{array}$ & Generał Broni \\
\hline $\begin{array}{l}\text { General } \\
\text { Officer }\end{array}$ & OF-7 & generálmajor & Major General & $\begin{array}{l}\text { Général de } \\
\text { Division }\end{array}$ & Generał Dywizji \\
\hline $\begin{array}{l}\text { General } \\
\text { Officer }\end{array}$ & OF-6 & $\begin{array}{l}\text { brigádní } \\
\text { generál }\end{array}$ & Brigadier General & $\begin{array}{l}\text { Général de } \\
\text { Brigade }\end{array}$ & Generał Brygady \\
\hline $\begin{array}{l}\text { Senior or } \\
\text { Field Grade } \\
\text { Officer }\end{array}$ & OF-5 & plukovník & Colonel & Colonel & Pułkovnik \\
\hline $\begin{array}{l}\text { Senior or } \\
\text { Field Grade } \\
\text { Officer }\end{array}$ & OF-4 & podplukovník & $\begin{array}{l}\text { Lieutenant } \\
\text { Colonel }\end{array}$ & $\begin{array}{l}\text { Lieutenant- } \\
\text { Colonel }\end{array}$ & Podpułkovnik \\
\hline $\begin{array}{l}\text { Senior or } \\
\text { Field Grade } \\
\text { Officer }\end{array}$ & OF-3 & major & Major & Commandant & Major \\
\hline $\begin{array}{l}\text { Junior } \\
\text { Officer }\end{array}$ & OF-2 & kapitán & Captain & Capitaine & Kapitan \\
\hline $\begin{array}{l}\text { Junior } \\
\text { Officer }\end{array}$ & OF-1 & $\begin{array}{l}\text { nadporučík } \\
\text { poruč́k }\end{array}$ & $\begin{array}{l}\text { First Lieutenant } \\
\text { Second Lieutenant }\end{array}$ & $\begin{array}{l}\text { Lieutenant } \\
\text { Sous-Lieutenant }\end{array}$ & $\begin{array}{l}\text { Porucznik } \\
\text { Podporucznik }\end{array}$ \\
\hline
\end{tabular}

\section{Závěr}

Tímto článkem jsem chtěl v prvé řadě poukázat na obtížnost překladu vojenských hodností. V druhé řadě jsem chtěl také poukázat na důležitost jakéhokoliv př̌kladu. Bez důkladné znalosti kulturních reálií, bez teoretického vzdělání v oblasti translatologie, dochází k chybným překladům, které mohou mít za následek fatální nedorozumění jak na úrovni strategické, tak operační a taktické.

Názvy hodností generálů a důstojníků lze překládat relativně snadněji než hodnosti nižší, tj. hodnosti praporčíků a poddůstojníků. Vlastní význam hodnosti generálů a vyšších důstojníků je na rozdíl od ostatních hodností relativně stabilní. Zastávané funkce se většinou u těchto hodností signifikantně neliší. U nižších hodností je situace podstatně komplikovanější. Je to způsobeno historickým vývojem a tradicemi jednotlivých členských států.

Při překladu vojenských hodností z češtiny do angličtiny nelze upřednostňovat úzus armády USA, Británie či jiného anglofonního státu, protože v mnoha př́padech vlastní význam názvů hodností u těchto armád nemusí bud' vủbec korespondovat s významem hodností v AČR, nebo se v tom lepším př́ípadě může překrývat, a to ještě v mnoha př́ipadech pouze částečně. To platí samozřejmě nejenom pro názvy vojenských hodností u anglofonních států, ale také pro názvy vojenských hodností u ostatních členských států 


\begin{tabular}{|c|c|c|c|c|c|c|c|c|c|c|}
\hline$\frac{\pi}{2}$ & 言亭 & 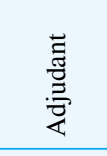 & 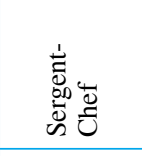 & 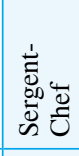 & 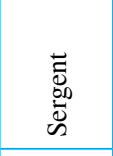 & 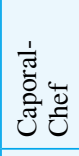 & 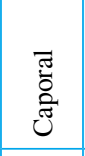 & 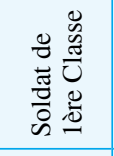 & $\begin{array}{l}\frac{\vec{\pi}}{0} \\
\frac{\pi}{0} \\
\text { in }\end{array}$ & \\
\hline 总 & 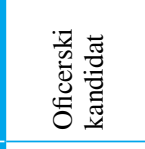 & 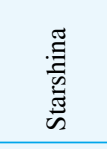 & 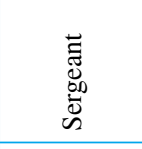 & 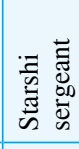 & 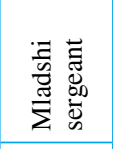 & 营 & $\begin{array}{l}\text { 弟 } \\
\text { 品 }\end{array}$ & $\begin{array}{l}\text { 竘 } \\
\text { ֻ }\end{array}$ & 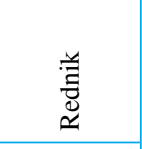 & \\
\hline$\frac{\pi}{2}$ & 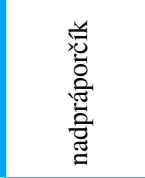 & 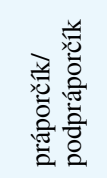 & 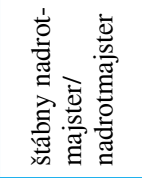 & 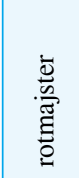 & 空 & 志 & 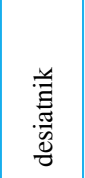 & $\begin{array}{l}\frac{.}{F_{0}} \\
\frac{0}{0} \\
\frac{0}{n}\end{array}$ & 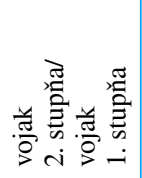 & \\
\hline 弚 & 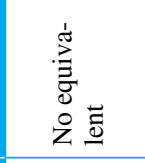 & 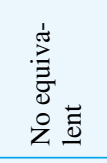 & & 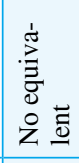 & 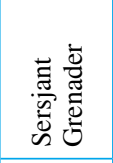 & 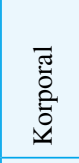 & 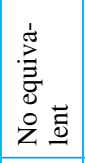 & 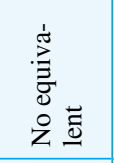 & & 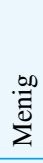 \\
\hline$\stackrel{\overrightarrow{0}}{2}$ & 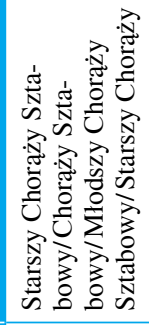 & 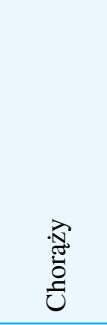 & & 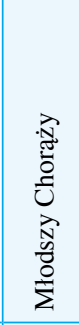 & 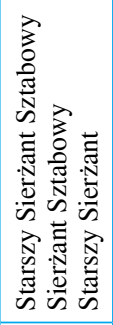 & 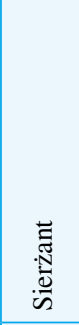 & 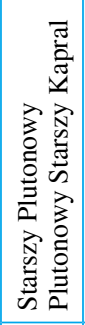 & 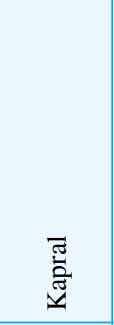 & 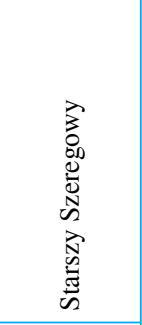 & 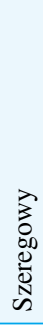 \\
\hline$\frac{z}{0}$ & 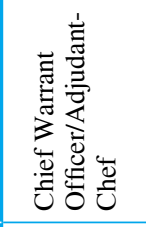 & 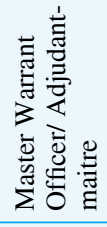 & 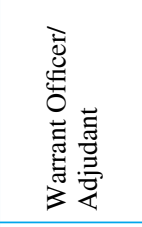 & 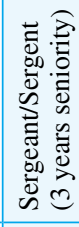 & 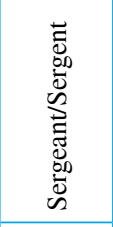 & 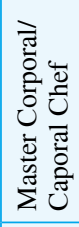 & 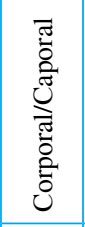 & 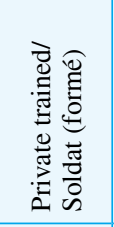 & 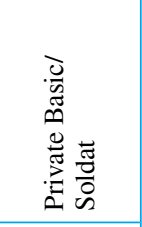 & \\
\hline 䓛 & 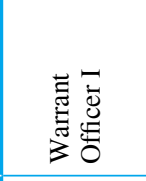 & 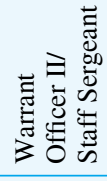 & 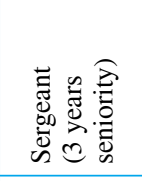 & 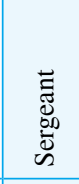 & $\begin{array}{l}\bar{\pi} \\
\text { : } \\
0 \\
0\end{array}$ & 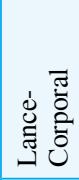 & 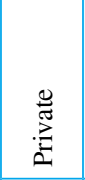 & 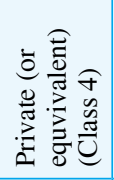 & & \\
\hline$\overleftarrow{b}$ & 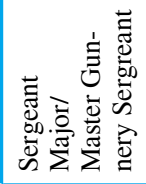 & 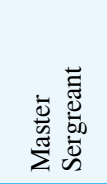 & 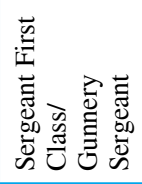 & 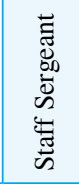 & 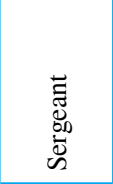 & 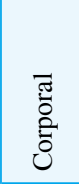 & 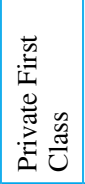 & 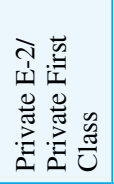 & 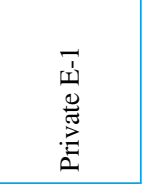 & \\
\hline 5 & 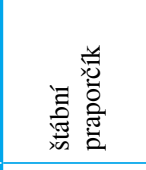 & 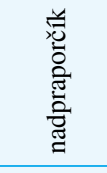 & 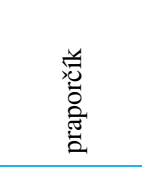 & 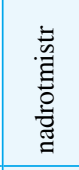 & 总 & 离 & 总 & $\begin{array}{l}\text { 弟 } \\
\text { 悹 } \\
\text { 岁 }\end{array}$ & 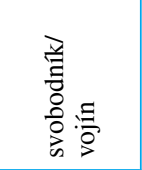 & \\
\hline $\begin{array}{l}0 \\
\frac{1}{2} \\
\frac{1}{2}\end{array}$ & $\begin{array}{l}\hat{\dot{d}} \\
\text { }\end{array}$ & $\begin{array}{l}\infty \\
\stackrel{i}{0}\end{array}$ & 光 & $\begin{array}{l}\text { lo } \\
\text { वे }\end{array}$ & $\begin{array}{l}\tilde{u} \\
\tilde{a}\end{array}$ & 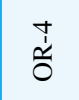 & 峁 & Ĩ & $\overrightarrow{\tilde{\sigma}}$ & \\
\hline
\end{tabular}


NATO. Při každém překladu vojenských hodností musíme vždy citlivě posoudit daný význam, sociálně-kulturní zvláštnosti, situační a slovní kontext, a poté se rozhodnout, zda přiřadíme hodnosti určitý hodnostní ekvivalent, nebo hodnost přeložíme opisem.

Názvy vojenských hodnosti jsou ve STANAGu 2116 sice uvedeny v národních jazycích, ale jejich překlady do angličtiny jsou národní záležitostí. Tyto překlady mohou někdy u účastníků mezinárodních misí způsobovat diskuze, týkající se porovnání názvů hodností. Takové debaty lze vždy snadno vyřešit odkazem na příslušný kód podle STANAGu 2116.

Přesto vlastní hodnostní označení zpo̊sobovalo a bude i nadále způsobovat určité komplikace osobám, které nejsou seznámeny s hodnostním označením, vojenskými a kulturními tradicemi jiných armád. Stř́ibřité hvězdy u praporčíků a zlatavé hvězdy u důstojníků naší armády budou například u Američanů vyvolávat asociace s hodnostním označením jejich generálů stejně, jako nově zavedené stříbřité hodnostní pásky u našich praporčíků se jim budou podvědomě spojovat s představou označení jejich nižších důstojníků.

Analogicky způsobuje problémy našim příslušníkům hodnostní označení některých armád, kde například dvě hvězdy označují hodnost plukovníka a tři hvězdy označují hodnost brigádního generála. Proto se asi žádnou úpravou hodnostních označení nevyhneme případům, kdy vyšší hodnosti, které poprvé přijdou do styku se zástupci jiných armád, budou jako první salutovat hodnostem nižším, a tak způsobovat docela zábavné situace.

Pokud už tedy dochází z nějakých důvodů ke změně v hodnostním označení, tak na každém návrhu změn by měl pracovat tým odborníků tak, aby se případný negativní dopad nově zaváděných změn omezil na minimum.

\section{Poznámky k textu:}

[1] Přesné kritérium pro stanovení, zda se jedná o jazyk nebo dialekt chybí. Černý (2008) uvádí: „Vždyt např. mezi arabskými dialekty jsou mnohem větší rozdíly než mezi češtinou a slovenštinou, a přesto se všechny považují za dialekty jednoho jazyka - arabštiny.“

[2] Myšlenkou vytvoření světového jazyka se zabýval i Jan Amos Komenský.

[3] Hieroglyfické písmo rozluštil Francouz J. F. Champollion.

[4] Slova odlétají, písmo zůstává.

[5] Vlastním jménem Hieronymus (cca 347-420). V době, kdy překládal Bibli, působil ve funkci papežského tajemníka a teologického poradce papeže Damasuse I.

[6] U nás tento obor jako samostatná vědní disciplína vzniká teprve v období po druhé světové válce.

[7] Determinuje se nejenom původ, vzdělání, sociální postavení, dialekt, ale i temperament autora promluvy či textu.

[8] Tato hodnost byla spojenci překládána jako generálmajor.

[9] Ve Francii vzniklo v 17. století označení kadet pro potomky šlechtických rodin, kteří nedědili majetek, a proto se věnovali vojenské kariére. Ludvík XIV. z nich vytvořil jednotky, z nichž se rekrutovali důstojníci. Z Francie tento způsob převzaly další evropské státy. V habsburské monarchii bylo toto pojmenování zavedeno $v$ roce 1763 jako hodnost.

[10] Obdobné krácení se používá i u hodností poručíků a seržantů. BOWYER, 2002, str. 46.

[11] NATO Training Mission in Iraq.

[12] Flag officer je označení generálů a jejich ekvivalentů u námořnictva a letectva. Termín vznikl u námořnictva.

[13] Např́ílad mankind ve významu lidstvo je stále častěji nahrazováno slovy human beings, humankind, human race atd. Výraz policeman bývá nahrazován výrazy police officer, nebo law enforcement officer, výraz fireman se nahrazuje termínem firefighter, weatherman se nahrazuje výrazy weather reporter, weathercaster nebo meteorologist atd. 

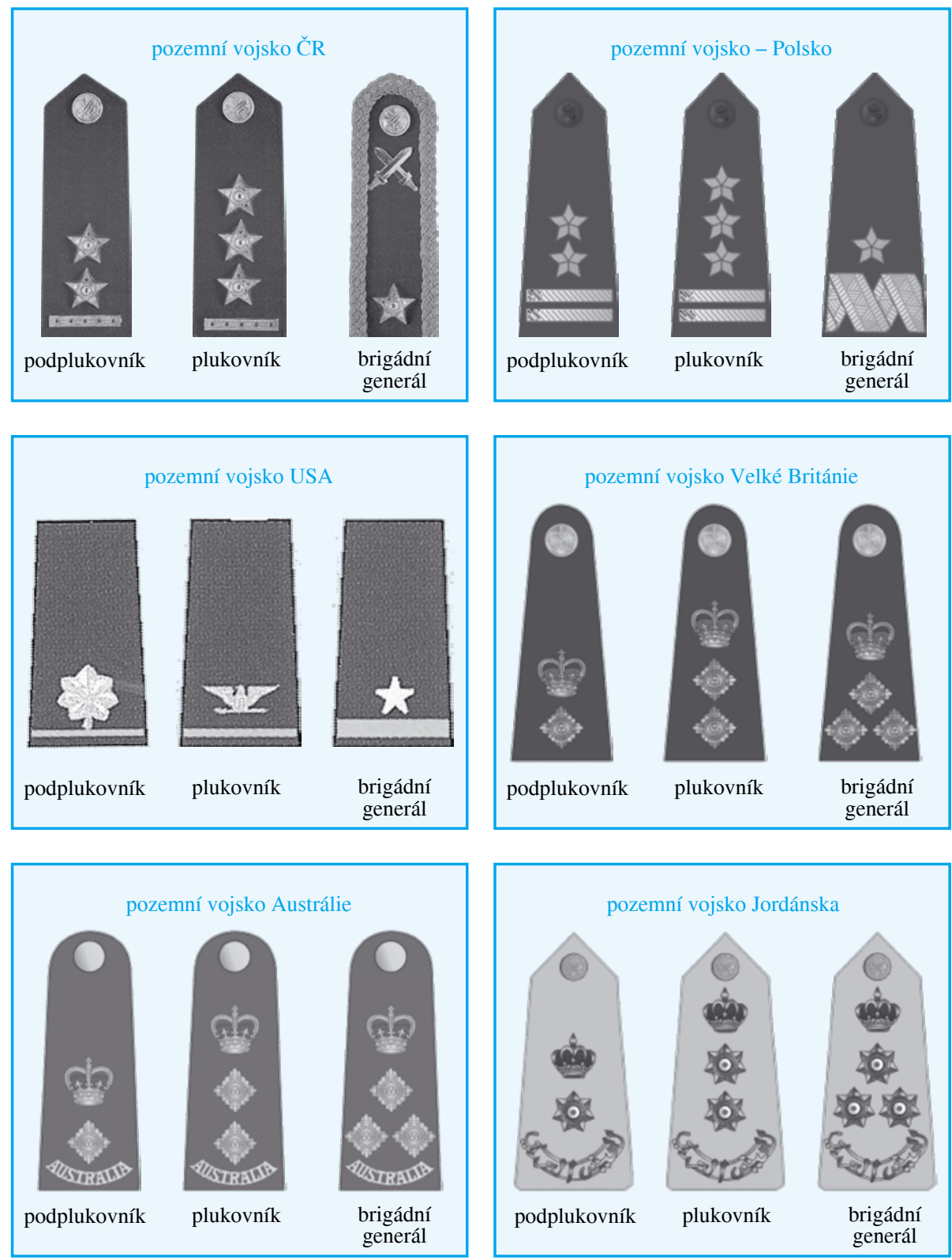

Obr.: Podplukovník, plukovník, brigádní generál.

Poznámka: Některé vojenské insignie jsou zavádějící i v poměrně souměřitelných hodnostech. Např. řada brigádních generálů hlavně $\mathrm{v}$ arabských zemích má tř̌ hvězdy, jež se pletou s naším plukovníkem. Jejich plukovník má dvě hvězdy jako náš podplukovník. 
[14] Enlisted viz dále v textu.

[15] V AČR se jedná o funkci.

[16] Tato hodnost/funkce byla vytvořená 4 . července 1966 a kancelář pro tuto osobu je $\mathrm{v}$ Pentagonu.

[17] Ottův slovník naučný uvádí, že praporčík vznikl ze slova praporečník: ,... když nošení praporu ve vojště ... v XVIII. stol. přeneseno s nejnižšího stupně důstojnického na poddůstojníka, zachoval se onomu název praporečníka, jenž pak změněn na praporčíka.“

[18] Poněkud jiná je situace $\mathrm{v}$ armádě Velké Británie. Zde se význam pojmu warrant officer přibližuje významu pojmu našeho praporčíka.

[19] Občas se jak překladech odborných, tak v beletrii objevuje pokus o zavedení termínu důstojnický zástupce ve významu warrant officer (např. Vogeltanz, Hus, 2005).

[20] Ottův slovník naučný uvádí, že v některých cizích armádách tato hodnost může zahrnovat generály, admirály či polní maršálky.

[21] Když hovoříme o termínu officer, můžeme se také setkat se složeninami jako např́klad Action Officer - štábní pracovník, který zodpovídá za určitý projekt nebo za určitou činnost, nebo Line Officer (officer of the line) - voják, který je přidělen k bojové jednotce (pěchota, dělostřelectvo).

[22] Termín General Officers je v plurálu kolektivní označení generálů a odpovídajících hodností u námořnictva nebo letectva, $v$ singuláru se jedná o nespecifikovanou hodnost generála.

[23] Např́klad ve válce v Perském zálivu byli povoláni znovu do armády „,vojáci v záloze - důchodci“ jednalo se o odborníky v určitých požadovaných specializacích.

[24] Officers, STANAG 2116, edice 6/2010 z 25. února 2010.

[25] Other Ranks, tamtéž.

\section{Bibliografie:}

CATFORD, J.C. A Linguistic Theory of Translation. OUP. 1974.

ČERNÝ, J. Dějiny lingvistiky. Praha: Votobia, 1996.

ČERNÝ, J. Úvod do studia jazyka. Olomouc: Rubico, 2008.

FIŠER, Z. Překlad jako kreativní proces. Brno: Host, s.r.o., 2009.

HEYMAN, Ch. The British Army. R\&F Defence Publications. 2000.

HRDLIČKA, M. Překladatelské miniatury. Praha: Karolinum, 1994.

KNITTLOVÁ, D. K teorii i praxi překladu. FF UP 2000, Olomouc.

KRIJTOVÁ, O. Pozvání k prekladatelské praxi. Praha: Karolinum, 1996.

KUFNEROVÁ, Z. Čtení o překládání. H\&H Vyšehradská, s.r.o., 2009.

LEVÝ, J. Umění překladu. Praha: Ivo Železný s.r.o., 1998.

MÜGLOVÁ, D. Komunikácia, tlmočenie, preklad. Praha: Enigma Publishing s.r.o., 2009.

URBANOVÁ, L. Stylistika anglického jazyka. Barrister \& Principal, 2008.

VILIKOVSKÝ, J. Překlad jako tvorba. Praha: Ivo Železný s.r.o., 2002.

VOGELTANZ, J.- HUS M. Vojáci studené války. Monatex, a. s., 2005

\section{Slovníky a encyklopedie:}

ARKIN, W. M. Encyclopedia of the U. S. Military. Ballinger Publishing Company, 1990.

BOWYER, R. Dictionary of Military Terms, Second edition, London: Peter Collin Publishing, 2002, 250p. ISBN 1-903856-20-5.

BOWYER, R. Dictionary of Military Terms. Fitzroy Dearborn Publishers, 1999.

BOWYER, R. Dictionary of Military Terms. Macmillan Publishers Limited, 2004

BOWYER, R. Dictionary of Military Terms. A \& C Black Publishers Ltd., 2007.

ČAPKA, F. Slovník českých a světových dějin. Akademické nakladatelství, s.r.o., 1998.

ROVENSKÝ, D. Profesionální, nebo profesionalizovaný poddůstojnický sbor? Vojenské rozhledy, 2008, roč. 17, č. 2, s. 136-156, ISSN 1210-3292.

TOMAJCZUK, S.F. Dictionary of the Modern United States Military. McFarland. 1996.

TRÁVNÍČEK, F. - Váša P. Slovník jazyka českého. Praha: Fr. Borový, 1937.

Lexikografický kolektiv, Slovník spisovného jazyka českého. Praha: Academia, 1989.

Ottův slovník naučný. Praha: J. Otto, 1888-1909.

Ústav pro jazyk český, Slovník spisovné češtiny pro školu a veřejnost. Praha: Academia, 1994.

Webová kniha o umění, dostupné z http://smarthistory.khanacademy.org/michelangelo-moses. 